\title{
Global Capital Inflows, Growth, and Trade Indicators in Ghana and Nigeria: Evidence from Asymmetric Cointegration Framework
}

\author{
Chukwuemeka Amaefule ${ }^{1 \star}$
}

${ }^{1}$ University of Port Harcourt, NIGERIA

*Corresponding Author: chukwuemekamaefule@gmail.com

Citation: Amaefule, C. (2020). Global Capital Inflows, Growth, and Trade Indicators in Ghana and Nigeria: Evidence from Asymmetric Cointegration Framework. European Journal of Sustainable Development Research, 4(4), em0130. https://doi.org/10.29333/ejosdr/8246

\section{ARTICLE INFO}

Received: 18 Mar. 2020

Accepted: 2 May. 2020

\begin{abstract}
This study examined the impact of the dynamical nature of Foreign Direct Investment (FDI) inflow and Officia Development Assistance (ODA) inflow on growth and trade indicators in Ghana and Nigeria. Secondary data sourced from World Development Indicators for the period covering 1970-2017 were utilized. The Nonlinear ARDL Bound F-test showed a long-run relationship between global capital inflows and growth and trade. Specifically, (i) positive (rise) FDI inflow generate a positive impact on RGDP in Ghana and negative impact on RGDP in Nigeria; negative (fall) FDI inflow leads to a positive impact on RGDP in Ghana and negative impact on RGDP in Nigeria (ii) positive ODA inflow causes a positive impact on RGDP in Ghana and Nigeria; negative ODA inflow has a negative impact on RGDP in Ghana and Nigeria (iii) positive and negative FDI (ODA) inflow has a negative impact on trade (\% of GDP) in Ghana and Nigeria (iv) positive and negative FDI inflow leads to a negative impact on multilateral trade in Ghana; and positive and negative FDI inflow leads to a positive impact on multilateral trade in Nigeria; (v) positive and negative ODA inflow leads to a negative impact on multilateral trade in Ghana and Nigeria (vi) positive and negative FDI inflow leads to a negative impact on trade openness in Ghana and positive impact in Nigeria, (vii) positive and negative ODA inflow has negative and positive impact on trade openness in Ghana and negative impacts in Nigeria.
\end{abstract}

Keywords: FDI inflow, ODA inflow, nonlinear ARDL, growth, trade

\section{INTRODUCTION}

The global economy is susceptible to dynamical changes. For example, the COVID-19 has generated structural and systemic delay in the investment outlook emanating from losses in global reinvestment earnings (a major component of FDI). Specifically, dynamical changes cause demand shock (e.g. COVID-19) and supply chain shock (e.g. slump in global oil price). jointly these shocks in tandem to previous shocks could potentially disrupt sustainable development goals (SDGs). It is based on these dynamical changes that this paper seeks to investigates the impact of changes in capital inflows on macroeconomic stability in Ghana and Nigeria. The outbreak of coronavirus (COVID-19) has lowered reinvested earning. Hardest hit sectors are viz; automotive industry $(-44 \%)$, airline $(-42 \%)$, and energy and basic materials industries (-13\%). Statistically, the implication of COVID-19 translates to $9 \%$ (world), $-6 \%$ (world economies), and $-16 \%$ (developing economies) earning losses in the global reinvested earnings. On average, FDI flow (could range between $-5 \%$ and $-15 \%$ in 2020) and other foreign investment will be affected by the negative effect on COVID-19 on the market seeking-, efficiency seeking-, and resource seeking- investment behaviour which will, in turn, affect the global value chain (UNCTAD, 2020).

The dynamical nature of FDI inflow and ODA inflow remains a policy concern for dependent economies such as Ghana and Nigeria. Global, FDI slumped by 13\% in 2018 from 2017. The flow was $\$ 1.5$ trillion in 2017 and declined to $\$ 1.3$ trillion in 2018 . But, in Africa FDI flow inflow grew from $\$ 41390$ to $\$ 45902$ between 2017 and 2018 . The continent, however, reached its peak in 2015 with $\$ 56874$ million. Capital inflows trend in West Africa is highly unstable. West Africa reached its peak in 2016 with an FDI inflow of $\$ 12,721$ million and declined to $\$ 9565$ in 2018. The inflow of FDI stock into West Africa grew from $\$ 171121$ million in 2016 to $\$ 186230$ million in 2017 reaching its peak in 2018 with a value of $\$ 194605$ million. In Nigeria, flows plunged by $43 \%$ to $\$$ billion and flows to Ghana also dipped, albeit by a more moderate $8 \%$ to $\$ 3$ billion (World Investment Report, UNCTAD, 2019).

The shock from COVID-19 could be overwhelming for Africa's sustainable development goals. The breakdown of FDI flows inflow shows that there was a decline in FDI flow from $\$ 3255$ million in 2017 to $\$ 2989$ million in 2018. FDI stock inflow grew from $\$ 33137$ million in 2017 to $\$ 36126$ million. In Nigeria, FDI inflow dropped from \$3503 million in 2017 to $\$ 1997$ million in 2018 , and its FDI stock inflow grew from $\$ 97687$ million in 2017 to $\$ 99685$ million in 2018 . For both Ghana and Nigeria, the percentage ratio of FDI inflows to gross fixed capital formation declined in 2018 to 22.3 in Ghana and 3.8 in Nigeria from 26.8 in Ghana and 6.3 in 
Nigeria in 2017. Similarly, the percentage of FDI stock to the ratio of gross domestic product dropped from 56.2 and 26.0 in 2017 to 55.4 and 25.1 in 2018 in Ghana and Nigeria respectively (UNCTAD's World Investment Report, 2019). ODA net flow received declined from \$1.3 billion to 1.2 billion in Ghana and grew from \$2.4 billion to \$3.3 billion in Nigeria from 2016 to 2017 (World Development Indicators, 2018).

Foreign investments are encouraged through the development of Special Economic Zones (SEZs). There are an estimated 237 SEZs in Africa, and 5, 383 globally some still under construction, along with more than 200 single-enterprise zones (so-called free points). SEZs operate in 38 of the 54 economies on the continent, with the second-highest number in Nigeria (38). In Ghana, there are only 4 SEZs. Despite the variation of SEZs between Ghana and Nigeria, an annual average growth rate of trade goods (CAGR in between 2007-2017) is 13\% in Ghana and -4\% in Nigeria; GVC integration (economies ranked by foreign value-added share (FVA share), 2017) is $8 \%$ in Ghana and 6\% in Nigeria. Presently, the COVID-19 is threatening global value chain, "the outbreak of coronavirus, showed a significant drop in the finalization process of cross-border acquisitions, to below $\$ 10$ billion from normal monthly values of $\$ 40-\$ 50$ billion." Thus, there are halts in production caused by negative demand shocks in economies most severely affected by the epidemics. Thus, GVC linkages are threatened by the drop in capital expenditures of MNEs (UNCTAD, 2020).

The slump in global oil price in 2020Q1 and 2020Q2 implies that gap is created in the current account of fiscal operation of developing economies. This therefore makes it increasingly difficult for the fiscal unit to finance its expenditures necessary to enhance SDGs. Thus, the weak capital account caused by COVID-19 and the decline in current account position of developing-oil dependent economies e.g. Nigeria and Ghana via slump in oil price summarises the major problems of this paper.

The motivating question, therefore, becomes how sustainable development goals can be affected in Ghana and Nigeria as fluctuation occurs in global capital inflow? How do volatility in the global capital inflow affected by reinvested global earning through global value chain (GVC) linkages, SEZs, merger and acquisitions (M\&A), and production in Multinational Enterprises (MNEs) affect growth and trade in Ghana and Nigeria? Thus, how do dynamical changes in FDI and ODA through the SEZ platform improve macroeconomic performances in Ghana and Nigeria? Specifically, to what extent do dynamical changes FDI inflow and ODA inflow impact on growth and trade in Ghana and Nigeria? These questions are motivated by the intimidating revelations in UNCTAD (2020), UNCTAD (2019), and UNCTAD (2018) reports on the volatile nature of the capital flows across Africa.

\section{Objective of the Study}

Specifically, this study seeks to:

1) Determine the dynamical impact of capital inflows on growth in Ghana and Nigeria.

2) Investigate the dynamical impact of capital inflows on trade in Ghana and Nigeria.

Hypothesis of the Study

1) The higher the capital inflows the higher the growth in Ghana and Nigeria.

2) Capital inflows lead to higher trade in Ghana and Nigeria.

\section{THEORETICAL LITERATURE}

The proponents of the financial liberalization hypothesis contend that financial repression affects growth. McKinnon (1973) and Shaw (1973) provide a robust argument on the global imperativeness of capital movement. More so, Chenery and Strout (1966) significantly argued that cross-border transmutation of capital could create capital formation and reduce savings ( $s g$ ) and investment (inv) gaps. It is based on the globalization of capital movement inflow impact on growth and trade indictors. The foregoing nature of globalization of capital movement informed the inevitability of this paper to distinctively investigate the dynamical effects of capital inflows on growth and trade indicators in Ghana and Nigeria.

\section{EMPIRICAL LITERATURE}

Sedai (2019) employed two instruments to study the cost and benefits of capital inflow on emerging and sub-Saharan economies. These instruments are namely panel Granger causality test and the fixed-effect panel regression method. From the findings, there exists strong bidirectional causality between FDI equity flows and growth, and; weak and lagged causality existing between short-run capital flows and growth. Ikpesu (2019) for the periods covering 1981-2016 in an OLS found that capital inflows have a significantly positive impact on growth in Nigeria. In a panel group study of 26 African countries, Mowlaei (2018) adopted pooled mean group analysis from 1992-2016, the study found that foreign capital inflows have long-run and short-run positive impact on economic growth. Between 1980 and 2015 in an ARDL environment; Ehigiamusoe and Lean (2019) found a cointegration relationship between capital inflows and growth. The study specifically observed that FDI and Aid have an insignificant impact on growth; foreign portfolio investment produced a positive impact on growth.

Anyanwu and Yameogo (2014) adopted OLS and GMM estimators. These instruments enabled the study to obtain mixed determinants of FDI inflow across the five regions studied. The determinants of FDI inflows are GDP per capita, trade openness, net foreign aid, political regimes and presence of democracy, level of infrastructural development, level of education, level of urbanization, and oil production. The findings showed that the FDI inflow varies regionally. Specifically, the study found the following effects are viz (a) the impact of FDI inflow on GDP per capita for all the five regions is positive, however, the impact of FDI inflow on GDP per capita is decreasing for Central Africa. But GDP growth rate has a strongly increasing impact only in Central 
Africa (b) trade openness has an increasing impact on FDI inflows in all the five regions but the effect is not statistically significant for East and Central Africa; (c) Net foreign aid has decreasing impact on FDI inflows in East, North, West, and Southern Africa; (d) Political regime type contributes increasingly and significantly towards attracting foreign investors in West Africa much so that democracy increasingly improved FDI inflow in Southern Africa; (e) the level of urbanization has a strong increasing impact on FDI inflow in East and Southern Africa as well as decreasing impact in West Africa; ( $f$ ) infrastructure development produced an increasing impact on FDI inflows in North and East Africa; $(\mathrm{g})$ the level of education has an increasing impact in West and North Africa; and (h) Oil production has a significantly increasing impact in West Africa.

Before the foregoing robust study conducted by Anyanwu and Yameogo (2014), Borensztein, De Gregorio, and Lee (1997) in a cross-country regression framework had earlier improved the literature by asserting that FDI generates the growth of technology, increases growth more and less determinant of investment. The study further opined that the functional relationship between FDI and growth is connected largely to the existing absorptive capacity of technology in the recipient (host) countries.

Also, Tang, Selvanathan, and Selvanathan (2008) utilized ECM technique and innovation accounting techniques for the period covering from 1988 to 2003 . The results showed that while there is bi-directional causality between domestic investment and economic growth, there is only single-directional causality from FDI to domestic investment and economic growth. Rather than crowding out domestic investment, FDI is found to be complementary with domestic investment. Thus, FDI catalyzes domestic investment and stimulates economic growth by capital value addition in China.

Ledyaeva and Linden (2006): studied FDI on GDP per capita in 74 Russian regions for the period covering 1996 to 2003 . The study employed Barro and Sala-I-Martin's empirical framework of the neoclassical Solow-Swan model. The Arellano-Bond GMMDIFF methodology, developed for dynamic panel data models, is used in estimations. The findings of the result are that in general FDI (or related investment components) does not contribute significantly to economic growth in Russia in the analyzed period. Similarly, the result found that regional growth in the periods from 1996 to 2003 could be attributed to factors such as the initial level of region's economic development, the 1998 financial crisis, domestic investments, and exports. However, some evidence of positive aggregate FDI effects in higher-income regions is relevant. The result findings decipher that convergence between poor and rich regions in Russia exists. However, FDI seems not to play any significant role in the recent growth convergence process among Russian regions. This study aligns with the conclusion that Carkovic and Levine (2002) exogenous components of FDI do not have an impact on growth.

Cem (2002) established that the panel cointegration test indicates that there is a long-run relationship between FDI and productivity variables. Thus, FDI accelerates labour productivity and is significantly different amongst developing nations. The findings are consistent with labour quality index of Bonthuis (2010). De Mello (1999) in his paper on the impact of FDI on capital accumulation, output, total factor productivity for OECD and non-OECD period covering 1970-90. The study found FDI is growthenhancing through technological upgrading and knowledge spillover.

\section{Originality and Value}

The papers reviewed failed to acknowledge the dynamical impact of capital inflows on growth and trade. There is absolute lack of consensus between scholars on the imperativeness of capital inflows on the economic outlook in developing economies. It is, therefore, pressing on this study to fill the existing gap through the application of a Nonlinear Autoregressive Dynamic Lag (NARDL) framework. This study significantly focused on broad-based target instruments that are strong economic determinants e.g. trade and growth, to achieving SDGs. The transmission link between growth and global trade on SDGs cannot be overemphasized. In tandem to the global agenda to achieve SDG goal, the threatening impact of COVID-19 outbreaks effect on global value chain and reinvested earning loss. On this basis, it is therefore expedient to examine the imminent danger of fluctuations of capital inflows impact in Ghana and Nigeria. However, because of paucity of data on capital inflow e.g. IBRD, FDI, and ODA in Ghana and Nigeria, this paper takes data sample size of capital inflow from 1970-2017.

\section{METHODOLOGY}

The economic and empirical argument for employing Nonlinear Autoregressive Distributed Lag (NARDL) assumes a nonlinearity framework due to asymmetric effect arising from partial sums of positive and negative changes over Autoregressive Distributed Lag (ARDL) linear model. It is based on the foregoing facts that NARDL provides better dynamical results over ARDL. Like ARDL, NARDL is a dynamic cointegrating model. In addition, NARDL is an improvement on the ARDL framework. NARDL provides a dynamical cointegrating model that illustrates the impact of increase and decrease in hypothesized (independent) variables on the targets (dependents) variable.

Following Pesaran and Shin (1998) ARDL, Nonlinear ARDL $(p, q)$ model is therefore given as

$$
\delta_{t}=\sum_{j=1}^{\rho} \emptyset_{j}, \delta_{t-j}+\sum_{j=0}^{q}\left(\theta_{j}^{+\prime} \tau_{t-j}^{+}+\theta_{j}^{-\prime} \tau_{t-j}^{-}\right)+\varepsilon_{t}
$$

Following Pesaran et al. (2001) ARDL in equation (1), Shin, Yu, Greenwood-Nimmo $(2011,2014)$ developed a NARDL, using dynamic autoregressive.

Given as 


$$
\begin{gathered}
\Delta \delta_{t}=\rho \delta_{t-1}+\theta^{+\prime} \tau_{t-1}^{+}+\theta^{-\prime} x_{t-1}^{-}+\sum_{j=1}^{\rho-1} \gamma_{j} \Delta \delta_{t-j}+\sum_{j=0}^{q-1}\left(u_{j=0}^{+\prime} \Delta \tau_{t-j}^{+}+u_{j}^{-1} \Delta \tau_{t-1}^{-}\right)+\varepsilon_{t} \\
=\rho \xi_{t-1}+\sum_{j=1}^{\rho-1} \gamma_{j} \Delta \delta_{t-j}+\sum_{j=0}^{q-1}\left(v_{j=0}^{+\prime} \Delta \tau_{t-j}^{+}+v_{j}^{-1} \Delta \tau_{t-1}^{-}\right)+\varepsilon_{t}
\end{gathered}
$$

Based on the NARDL framework developed by Shin, Yu, Greenwood-Nimmo (2011), we built our model for this study. Further modifications were inputted to reflect the major objective of this paper.

$$
\begin{aligned}
& \Delta \operatorname{LnRGDP}_{m 1-2 t}=3+\Omega_{0} \operatorname{LnRGDP}_{t-1}+\Omega_{1} \operatorname{LnFDI}_{t-1}^{+}+\Omega_{2} \operatorname{LnFDI}_{t-1}^{-}+\Omega_{3} \operatorname{LnODA}_{t-1}^{+}+\Omega_{4} L n O D A_{t-1}^{-}+\Omega_{5} \operatorname{LnIBRD}_{t-1}^{C V} \\
& +\sum_{i=1}^{\rho} \theta \Delta L n R G D P_{t-1}+\sum_{i=0}^{\sigma}\left(\gamma_{i}^{+} \Delta L n F D I_{t-1}^{+}+\gamma_{i}^{-} \Delta L n F D I_{t-1}^{-}\right)+\sum_{i=0}^{\omega}\left(\varnothing_{i}^{+} \Delta L n O D A_{t-1}^{+}+\emptyset_{i}^{-} \Delta L n O D A_{t-1}^{-}\right)+\mu_{t} \\
& \Delta \operatorname{LnTRD}_{m 1-2 t}=3+\beta_{0} \operatorname{LnTRD}_{t-1}+\Omega_{1} \operatorname{LnFDI}_{t-1}^{+}+\Omega_{2} \operatorname{LnFDI}_{t-1}^{-}+\Omega_{3} \operatorname{LnODA}_{t-1}^{+}+\Omega_{4} \operatorname{LnODA}_{t-1}^{-}+\Omega_{5} \operatorname{LnIBRD}_{t-1}^{C V} \\
& +\sum_{i=1}^{\rho} \theta \Delta L n T R D_{t-1}+\sum_{i=0}^{\sigma}\left(\gamma_{i}^{+} \Delta L n F D I_{t-1}^{+}+\gamma_{i}^{-} \Delta L n F D I_{t-1}^{-}\right)+\sum_{i=0}^{\omega}\left(\varnothing_{i}^{+} \Delta L n O D A_{t-1}^{+}+\emptyset_{i}^{-} \Delta L n O D A_{t-1}^{-}\right)+\mu_{t} \\
& \Delta L n M L T_{m 1-2 t}=3+\Omega_{0} L n M L T_{t-1}+\Omega_{1} L_{L n F D I_{t-1}^{+}}+\Omega_{2} \operatorname{LnFDI}_{t-1}^{-}+\Omega_{3} L n O D A_{t-1}^{+}+\Omega_{4} L n O D A_{t-1}^{-}+\Omega_{5} \operatorname{LnIBRD}_{t-1}^{C V} \\
& +\sum_{i=1}^{\rho} \theta \Delta L n M L T_{t-1}+\sum_{i=0}^{\sigma}\left(\gamma_{i}^{+} \Delta L n F D I_{t-1}^{+}+\gamma_{i}^{-} \Delta L n F D I_{t-1}^{-}\right)+\sum_{i=0}^{\omega}\left(\emptyset_{i}^{+} \Delta L n O D A_{t-1}^{+}+\emptyset_{i}^{-} \Delta L n O D A_{t-1}^{-}\right)+\mu_{t} \\
& \Delta \operatorname{LnTRB}_{m 1-2 t}=3+\Omega_{0} \operatorname{LnTRB}_{t-1}+\Omega_{1} \operatorname{LnFDI}_{t-1}^{+}+\Omega_{2} \operatorname{LnFDI}_{t-1}^{-}+\Omega_{3} \operatorname{LnODA}_{t-1}^{+}+\Omega_{4} \operatorname{LnODA}_{t-1}^{-}+\Omega_{5} \operatorname{LnIBRD}_{t-1}^{C V} \\
& +\sum_{i=1}^{\rho} \theta \Delta L n T R B_{t-1}+\sum_{i=0}^{\sigma}\left(\gamma_{i}^{+} \Delta L n F D I_{t-1}^{+}+\gamma_{i}^{-} \Delta L n F D I_{t-1}^{-}\right)+\sum_{i=0}^{\omega}\left(\emptyset_{i}^{+} \Delta L n O D A_{t-1}^{+}+\emptyset_{i}^{-} \Delta L n O D A_{t-1}^{-}\right)+\mu_{t}
\end{aligned}
$$

In equation (3-6); $\mathrm{FDI}^{+}, \mathrm{FDI}^{-}, \mathrm{ODA}^{+}$, and $\mathrm{ODA}^{-}$are the respective partial sums of positive and negative changes in the regressors. IBRD is held constant (check variable). Thus, FDI and ODA are calculated as follows;

$$
\begin{aligned}
& \operatorname{LnFDI}_{t}^{+}=\sum_{i=1}^{t} \Delta F D I_{t}^{+}=\sum_{i=1}^{t} \max \left(\Delta F D I_{t}, 0\right) \text { and } \\
& L n F D I_{t}^{-}=\sum_{i=1}^{t} \Delta F D I_{t}^{-}=\sum_{i=1}^{t} \min \left(\Delta F D I_{t}, 0\right)
\end{aligned}
$$

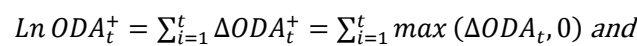

$$
\begin{aligned}
& L n O D A_{t}^{-}=\sum_{i=1}^{t} \Delta O D A_{t}^{-}=\sum_{i=1}^{t} \min \left(\triangle O D A_{t}, 0\right)
\end{aligned}
$$

Where $\Delta$ is the difference, $\beta i$ account for slope coefficient, $E C_{i}$ speed of adjustments, $X_{i t}$ represents regressors, $D U M_{i}$ captures dummy variables in intercept, and $Y_{i t}$ regressand (dependent variable), FDI= foreign direct investment, IBRD=International bank for reconstruction and development, ODA= official development assistance, RGDP= Real Gross Domestic Product, TRD=trade size (proxy by trade\% of GDP), MLT= multilateral trade, $\mathrm{TRB}=$ trade robustness. $\mathrm{m} 1=\mathrm{Ghana}, \mathrm{m} 2=\mathrm{Nigeria}$.

The Akaike selection criterion was critically considered for this study. This is because Akaike minimizes the expected dissimilarity, measured between the chosen model and the true model (i.e. the probability distribution that generated the data) model performed better in the class of other criteria. The model followed

$c$ ( $p$ lags of dependent and q lags of independent variable).

\section{Graphical Illustration}

The below graphical display is a visual representation of hypothesized variables in Ghana and Nigeria. 
Ghana

FDI

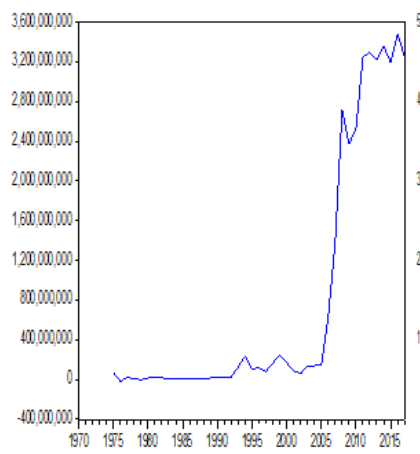

TRD

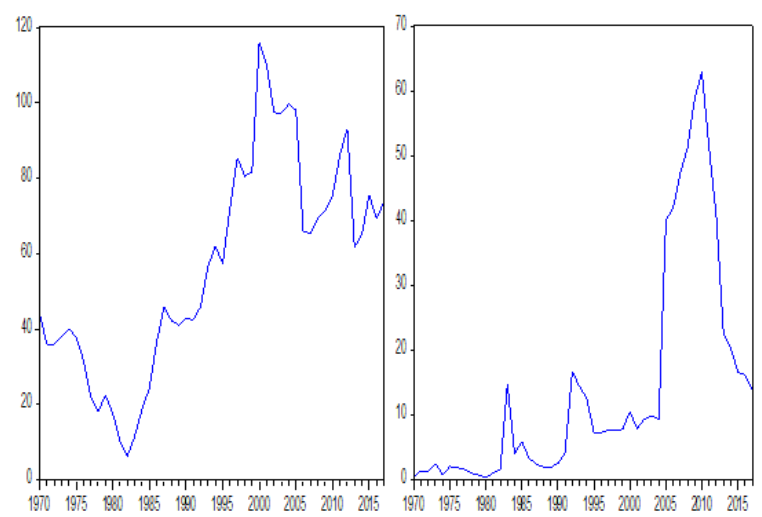

BCD

MT

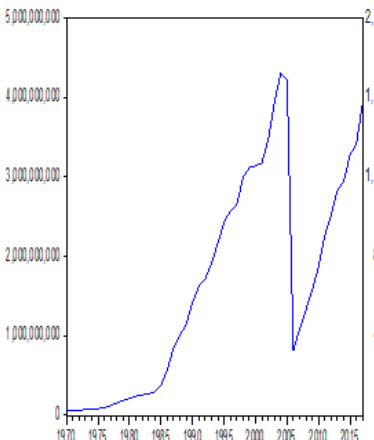

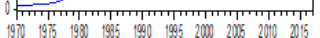

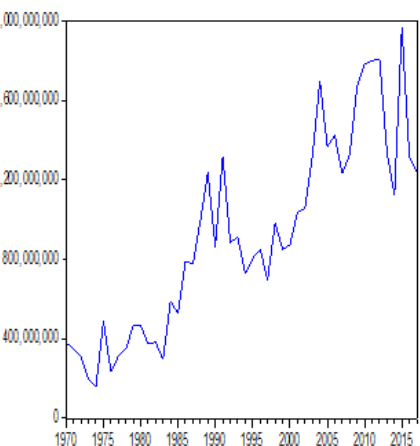

TRB

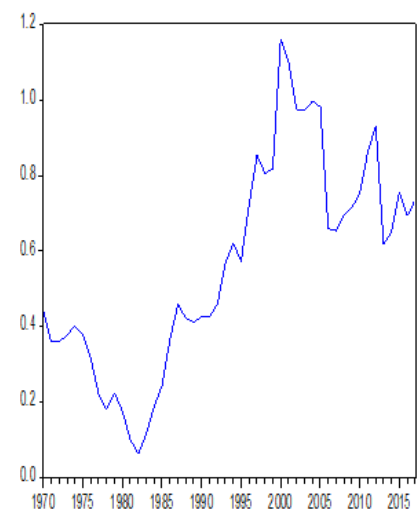

RGDP

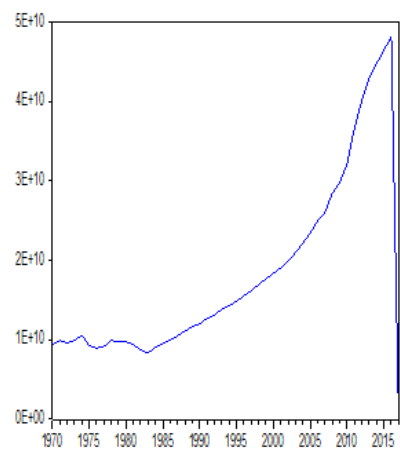

Figure 1. Trend Analysis of FDI, ODA, IBRD, RGDP, TRD, MLT, and TRB

\section{Nigeria}

RGDP

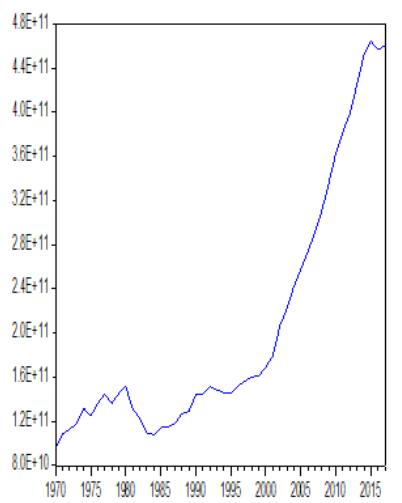

BRD

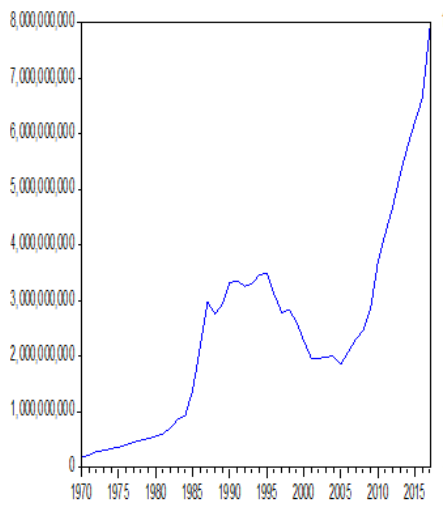

TRD

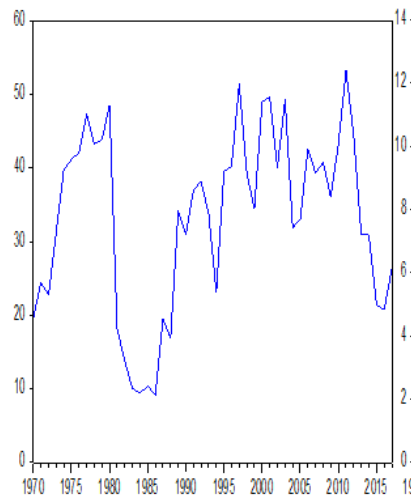

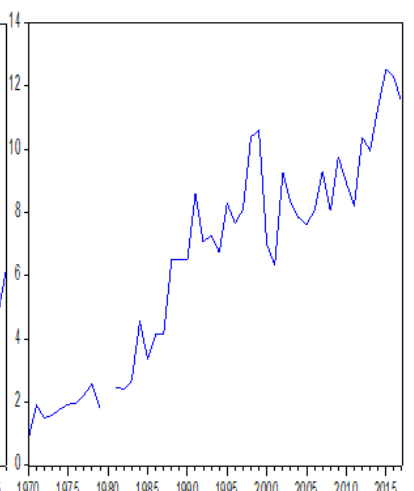

FD

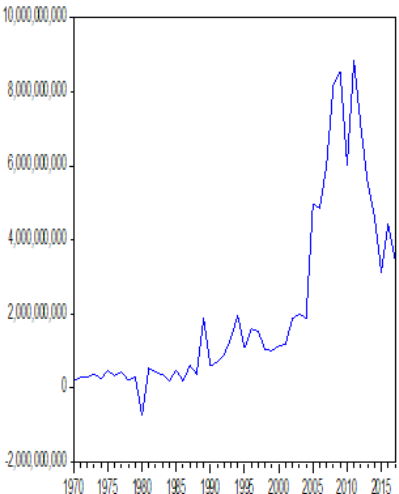

ODA

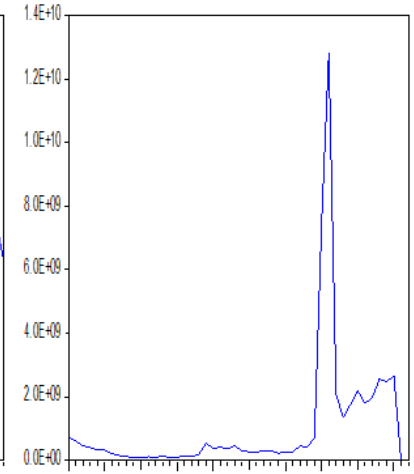

Figure 2. Trend Analysis of FDI, ODA, IBRD, RGDP, TRD, MLT, and TRB 
Table 1. ADF Unit Root Tests

\begin{tabular}{cccccccc}
\hline Country & RGDP & TRD & MLT & TRB ${ }^{\text {CV }}$ & FDI & IBRD \\
\hline Ghana & $\mathrm{I}(1)$ & $\mathrm{I}(1)$ & $\mathrm{I}(1)$ & $\mathrm{I}(1)$ & $\mathrm{ODA}$ & $\mathrm{I}(1)$ & $\mathrm{I}(1)$ \\
\hline Nigeria & $\mathrm{I}(1)$ & $\mathrm{I}(1)$ & $\mathrm{I}(1)$ & $\mathrm{I}(1)^{*}$ & $\mathrm{I}(1)$ & $\mathrm{I}(1)$ & $\mathrm{I}(0)$ \\
\hline
\end{tabular}

Source: Author's computation from Eviews 9.

Table 2. FDI Inflow and Real Growth

\begin{tabular}{|c|c|c|c|}
\hline & & Ghana & Nigeria \\
\hline Bound Test & Fstat & $1.463^{*}$ & 7.4056 \\
\hline \multirow{2}{*}{$\% 5$} & $I 0$ & 2.86 & 2.86 \\
\hline & $I 1$ & 4.01 & 4.01 \\
\hline Cointeg EQ & Coeffient & $40.290^{*}$ & -1.62388 \\
\hline \multirow{5}{*}{ LongRunForm } & Pvalue & $(0.0761)$ & $(0.000)$ \\
\hline & FDIpos & $\begin{array}{c}0.01815 \\
(0.1212)\end{array}$ & $\begin{array}{l}-0.00642 \\
(0.7268)\end{array}$ \\
\hline & FDIneg & $\begin{array}{c}0.01465 \\
\left(0.4655^{*}\right) \\
\end{array}$ & $\begin{array}{l}-0.04247 \\
\left(0.0912^{*}\right) \\
\end{array}$ \\
\hline & $O D A$ & $\begin{array}{c}-0.04569 \\
\left(0.5804^{*}\right) \\
\end{array}$ & $\begin{array}{c}-0.02322 \\
\left(0.0676^{*}\right)\end{array}$ \\
\hline & $I B R D$ & $\begin{array}{c}0.017220 \\
\left(0.4369^{*}\right) \\
\end{array}$ & $\begin{array}{c}-0.0828 \\
(0.004)\end{array}$ \\
\hline \multirow{6}{*}{$\begin{array}{l}\text { Diagnostics } \\
\text { Pvalues }\end{array}$} & Ramsey RT Stability & $0.000^{*}$ & $0.0088^{*}$ \\
\hline & HTBPG & 0.0528 & 0.9111 \\
\hline & LMT & 0.4718 & 0.977 \\
\hline & Normality & $0.000^{*}$ & 0.53293 \\
\hline & CUMSUM & WB & WB \\
\hline & CUMSUM SQUARES & NWB & WB \\
\hline ARDL selected Model & Akaike Info Criterion & $(2,0,0,4,1)$ & $(4,3,3,4,0)$ \\
\hline
\end{tabular}

Source: Author's computation from Eviews 9, NWB=Not Well Behaved; WB= Well Behaved

Why we need the ADF test? The ADF test is used to ascertain the suitability and reliability of hypothesized variables (both the dependent and independent) employed in this study. ADF is a unit root test for stationarity. Figures $\mathbf{1}$ and $\mathbf{2}$ have a trend. It simply implies that the time series could have unit root. To justify the application of the variables it is apt to conduct unit root test. It is based on the nature of the trend, we employed Augmented Dickey-Fuller (ADF) unit root test to test for estimating the stationarity and non-stationarity of results. Based on the results, the time series data were $I(1)$ and $I(0)$ none were $I(2)$ see Table 1 . Furthermore, $I(0)$ and $I(1)$ simply implies that the time series data were stationary at levels and stationary at first difference respectively.

Table 1 is an ADF test result for Ghana and Nigeria. The variables considered are the RGDP, TRD, MLT, TRB, FDI, IBRD, and ODA. Table 1 shows results obtained from ADF unit root for selected variables such as Real GDP (RGDP), Trade \% GDP (TRD), Multilateral Trade, Trade Robustness (openness), FDI inflow, IBRD inflow, and ODA inflow. The ADF unit shows that only ODA inflow variable in Nigeria was stationary at levels i.e. I(0). The other hypothesised variables were stationary at first differencing i.e. I(1). ADF unit root tests the null hypothesis that a unit is present in a times series sample at 5 percent. So a given time series be $I(0), I(1)$, but none should be I(2). The conclusion we could derive from Table 1 is that the variables are suitable for empirical analyses. Table 1 is a combination of data at levels and data at first differencing.

Thus, based on the outcome in Table 1, the data are fulfilling the condition to undertake NARDL. Hence, based on the result from Table 1 we proceed with the empirical analysis using NARDL framework. The results from NARDL are given as thus.

Table 2 displayed the dynamical impact of FDI inflow on RGDP under the NARDL framework. The purpose of this table is to deepen the impact study of FDI in West Africa to understand the rationale for the various variations in macroeconomic outlook. Ghana and Nigeria are considered in this study.

From Table 2, the bound test shows that there is no long-run relationship between FDI inflows and Real growth in Ghana and there exist a long-run relationship between FDI inflows and Real growth in Nigeria (see Bound F test result). The corresponding cointegration equation value is well behaved in Nigeria and not well behaved in Ghana. The negative sign proves the bound test is a good predictor of the long-run relationship between FDI inflows and Real growth in Nigerian. It is also confirmed that shortrun adjustment to long-run equilibrium between FDI and RGDP is unattainable in Ghana.

Following the established a mixed long-run relationship in Nigeria and in Ghana. It is proper to consider the impact of an increase and decrease in FDI inflow on Real GDP in Nigeria and Ghana. An increase in FDI inflow has a negative impact on growth in Nigeria. A one percent change in FDI inflows reduces growth in Nigeria by $0.6 \%$. Also, The impacts of decreases in the inflow of FDI bring about a slump in growth in Nigeria by $4.2 \%$. The impact of an increase and decrease in FDI inflows generates insignificant values in Ghana and Nigeria. However, in the long-run, a percentage change in FDI inflows affects growth in Ghana and Nigeria differently. Ghana did not meet the conditions for long-run hence the impact was not captured.

Also, in Table 3, the bound test result is consistent with Table 2. The bound test results showed that there is no long-run relationship between ODA inflow and real growth in Ghana. But long-run exists between ODA inflow on real growth in Nigeria. This is because of the Fstat. in Ghana are 3.29 less than the upper bound limit at 5 percent and Fstat in Nigeria is 6.99 greater than the upper and lower bound limit at 5\%. The result implies that ODA inflow into Ghanaian economy within the period of 1970-2017 do not have equilibrium relationship with Real growth. From Table 3, ODA inflow is not co-integrated Real GDP, and do not have long- 
Table 3. ODA Inflows and Real Growth

\begin{tabular}{|c|c|c|c|}
\hline & & Ghana & Nigeria \\
\hline Bound Test & Fstat & $3.29^{*}$ & 6.995 \\
\hline \multirow{2}{*}{$\% 5$} & $I 0$ & 2.46 & 2.46 \\
\hline & $I 1$ & 4.01 & 4.01 \\
\hline Cointeg EQ & Coeffient & $55.3131^{*}$ & -1.33529 \\
\hline \multirow{5}{*}{ LongRunForm } & Pvalue & $(0.1867)$ & $(0.0002)$ \\
\hline & $F D I$ & $-0.04453\left(0.269^{*}\right)$ & $-0.06157(0.0381)$ \\
\hline & ODApos & $0.05075\left(0.3427^{\star}\right)$ & $0.01415\left(0.1442^{*}\right)$ \\
\hline & ODAneg & $-0.1441\left(0.3923^{*}\right)$ & $-0.03976(0.0248)$ \\
\hline & $I B R D$ & $-0.04862\left(0.3087^{*}\right)$ & $-0.0435(0.0015)$ \\
\hline \multirow{6}{*}{$\begin{array}{c}\text { Diagnostics } \\
\text { Pvalues }\end{array}$} & Ramsey RT Stability & $0.0000^{*}$ & 0.2565 \\
\hline & HTBPG & 0.8022 & 0.4730 \\
\hline & $L M T$ & 0.6283 & 0.1572 \\
\hline & Normality & 0.09755 & 0.7566 \\
\hline & CUMSUM & WB & WB \\
\hline & CUMSUM SQUARES & NWB & NWB \\
\hline ARDL selected Model & Akaike Info Criterion & $(4,4,4,2,3)$ & $(4,1,2,4,2)$ \\
\hline
\end{tabular}

Source: Author's computation from Eviews 9, NWB=Not Well Behaved; WB= Well Behaved

Table 4. FDI Inflow and Trade (\% of GDP)

\begin{tabular}{|c|c|c|c|}
\hline & & Ghana & Nigeria \\
\hline Bound Test & Fstat & 7.382 & 7.263 \\
\hline \multirow{2}{*}{$\% 5$} & $I 0$ & 2.86 & 2.86 \\
\hline & $I 1$ & 4.01 & 4.01 \\
\hline Cointeg EQ & Coeffient & -1.10705 & -1.78515 \\
\hline \multirow{5}{*}{ LongRunForm } & Pvalue & $(0.0000)$ & $(0.0000)$ \\
\hline & LnFDIpos & $-0.05378(0.0101)$ & $-0.1613\left(0.118^{*}\right)$ \\
\hline & LnFDIneg & $-0.16301(0.0068)$ & $-0.2427\left(0.0747^{*}\right)$ \\
\hline & $\operatorname{LnODA}$ & $-0.13011\left(0.3273^{*}\right)$ & $0.173272(0.0146)$ \\
\hline & LnIBRD & $-0.00291\left(0.9565^{\star}\right)$ & $-0.18493\left(0.0818^{*}\right)$ \\
\hline \multirow{6}{*}{$\begin{array}{l}\text { Diagnostics } \\
\text { Pvalues }\end{array}$} & Ramsey RT Stability & 0.6868 & 0.4976 \\
\hline & HTBPG & 0.4312 & 0.9680 \\
\hline & $L M T$ & 0.6973 & 0.3870 \\
\hline & Normality & 0.6241 & 0.7620 \\
\hline & CUMSUM & WB & WB \\
\hline & CUMSUM SQUARES & WB & WB \\
\hline ARDL selected Model & Akaike Info Criterion & $(2,0,0,0,1)$ & $(2,3,3,4,1)$ \\
\hline
\end{tabular}

Source: Author's computation from Eviews 9; WB= Well Behaved

run implications on Real GDP. Thus, we could say that ODA inflow do not have impact on Real GDP. Hence, the results of the NARDL would not be explained for Ghana.

Table 3 portrays the asymmetric impact of ODA inflow on growth in Nigeria. The extent of the impact on growth by any perceptible change in the increase in ODA inflow into Nigeria is positive. The impact compels a $1.4 \%$ change on RGDP in Nigeria. Also, a decrease in ODA inflow generates a negative impact on growth by $3.9 \%$ in Nigeria. The model has a CUMSUM squares problem. These problems were remedied by augmenting the model with structural breaks dummy variables.

The model in Tables 4 and $\mathbf{5}$ are stable with CUMSUM and CUMSUM square and other diagnostic results are well behaved. The impact of FDI inflows and ODA inflows on trade (\% of GDP) in Ghana and Nigeria is presented in Tables 4 and 5 . Table 4 shows that FDI inflow have a long-run relationship with trade (\% of GDP) because the bound Fstat is greater than the upper and lower bound level e.g. Fstat. are 14.06 and 14.46 greater than upper bound limit at 5 percent in Ghana and Nigeria respectively. In the long-run, an increase in FDI inflow reduces trade (\% of GDP) by $5.3 \%$ in Ghana and $16.13 \%$ in Nigeria (see Table 4).

On the other hand, ODA inflow into Ghana and Nigeria has a long-run relationship with trade (\% of GDP). In Table 5, an increase and decrease in ODA inflows have both negative impacts on trade (\% of GDP). Trade (\% of GDP) declined by $19.7 \%$ in Ghana and $0.9 \%$ in Nigeria with a proportional rise in ODA inflow and trade (\% of GDP) declined by $0.5 \%$ and $0.2 \%$ in Ghana and Nigeria respectively with a proportional fall in ODA inflow into Ghana and Nigeria. 
Table 5. ODA Inflows and Trade (\% of GDP)

\begin{tabular}{|c|c|c|c|}
\hline & & Ghana & Nigeria \\
\hline Bound Test & Fstat & 14.06 & 14.46 \\
\hline \multirow{3}{*}{$\begin{array}{c}\% 5 \\
\text { Cointeg EQ }\end{array}$} & I0 & 2.86 & 2.86 \\
\hline & $I 1$ & 4.01 & 4.01 \\
\hline & Coeffient & -2.45519 & -1.19717 \\
\hline \multirow{5}{*}{ LongRunForm } & Pvalue & $(0.0000)$ & $(0.0000)$ \\
\hline & $F D I$ & $-0.05179(0.0378)$ & $0.17186\left(0.1560^{*}\right)$ \\
\hline & ODApos & $-0.1979(0.0029)$ & $-0.0999\left(0.0838^{*}\right)$ \\
\hline & ODAneg & $-0.0575\left(0.4787^{*}\right)$ & $-0.0200\left(0.2207^{*}\right)$ \\
\hline & IBRD & $-0.0098\left(0.7128^{*}\right)$ & $0.05936\left(0.3964^{\star}\right)$ \\
\hline \multirow{6}{*}{$\begin{array}{l}\text { Diagnostics } \\
\text { Pvalues }\end{array}$} & Ramsey RT Stability & 0.0533 & 0.2346 \\
\hline & HTBPG & 0.2005 & 0.9650 \\
\hline & LMT & 0.5842 & 0.1808 \\
\hline & Normality & 0.9717 & $0.0000^{*}$ \\
\hline & CUMSUM & WB & WB \\
\hline & CUMSUM SQUARES & WB & WB \\
\hline ARDL selected Model & Akaike Info Criterion & $(3,4,3,4,3)$ & $(1,2,1,0,3)$ \\
\hline
\end{tabular}

Source: Author's computation from Eviews 9; WB= Well Behaved

Table 6. FDI Inflows and Multilateral Trade

\begin{tabular}{|c|c|c|c|}
\hline & & Ghana & Nigeria \\
\hline Bound Test & Fstat & 4.13 & 9.31 \\
\hline \multirow{2}{*}{$\% 5$} & $I 0$ & 2.86 & 2.86 \\
\hline & $I 1$ & 4.01 & 4.01 \\
\hline Cointeg EQ & Coeffient & -1.42132 & -2.4767 \\
\hline \multirow{5}{*}{ LongRunForm } & Pvalue & $(0.00002)$ & $(0.0000)$ \\
\hline & LnFDIpos & $-0.000\left(0.3136^{\star}\right)$ & $0.00598\left(0.7086^{\star}\right)$ \\
\hline & LnFDIneg & $-0.0000(0.6926)$ & $0.02866\left(0.2975^{*}\right)$ \\
\hline & $\operatorname{LnODA}$ & $-0.000\left(0.2203^{*}\right)$ & $0.00023(0.9273)$ \\
\hline & LnIBRD & $-0.000\left(0.6102^{*}\right)$ & $-0.18493\left(0.1771^{\star}\right)$ \\
\hline \multirow{6}{*}{$\begin{array}{l}\text { Diagnostics } \\
\text { Pvalues }\end{array}$} & Ramsey RT Stability & $0.0270^{*}$ & 0.8145 \\
\hline & HTBPG & 0.3946 & 0.9616 \\
\hline & $L M T$ & 0.5089 & 0.2438 \\
\hline & Normality & $0.0000^{*}$ & 0.5053 \\
\hline & CUMSUM & WB & WB \\
\hline & CUMSUM SQUARES & NWB & WB \\
\hline ARDL selected Model & Akaike Info Criterion & $(4,0,0,1,0)$ & $(3,3,1,0,0)$ \\
\hline
\end{tabular}

Source: Author's computation from Eviews 9, NWB=Not Well Behaved; WB= Well Behaved

Multilateral trade is used to capture merchandise of export within the region (World Development Indicators). The CUMSUM squares could be explained by structural changes could have affected the productivity of FDI inflow in Ghana. Table 6 investigates the impact of FDI inflow on multilateral trade within Ghana and within the Nigerian region. The justification for this analysis is to deepen the impact of FDI inflow on trade in Ghana and Nigeria. The coefficient of the Bound F-test is greater than the critical values of an upper and lower level. This implies that there is a long-run relationship between FDI inflow and multilateral trade. In Ghana, any percentage change in the increase and decrease of FDI inflow results in zero elastic change in multilateral trade. Also, in Nigeria, any perceptible rise and fall in FDI inflow result in $0.5 \%$ and $2.8 \%$ change in multilateral trade respectively. The impact of changes in FDI inflow into Ghana and Nigeria on multilateral trade is statistically insignificant. In Table 7, ODA inflow has a longrun relationship with multilateral trade.

Similarly, ODA inflow contributes negatively to multilateral trade in Ghana and Nigeria. The increase and decrease in ODA inflow generate negative $0 \%$ and $0.5 \%$ impact on multilateral trade in Ghana and $0.1 \%$ and $0.2 \%$ impact in multilateral trade in Nigeria. The impact of ODA inflow is statistically insignificant. 
Table 7. ODA Inflows and Multilateral Trade

\begin{tabular}{|c|c|c|c|}
\hline & & GHANA & NIGERIA \\
\hline Bound Test & Fstat & 4.629 & 8.549 \\
\hline \multirow{2}{*}{$\% 5$} & I0 & 2.86 & 2.86 \\
\hline & $I 1$ & 4.01 & 4.01 \\
\hline Cointeg EQ & Coeffient & -1.5474 & -2.5232 \\
\hline \multirow{5}{*}{ LongRunForm } & Pvalue & $(0.0002)$ & $(0.0000)$ \\
\hline & $F D I$ & $-0.0000\left(0.1799^{*}\right)$ & $0.00085\left(0.9852^{*}\right)$ \\
\hline & ODApos & $-0.000\left(0.7257^{*}\right)$ & $-0.01190\left(0.5609^{*}\right)$ \\
\hline & oDAneg & $-0.0575\left(0.7523^{\star}\right)$ & $-0.0200\left(0.4477^{*}\right)$ \\
\hline & $\begin{array}{l}B R D \\
\end{array}$ & $-0.0000\left(0.4386^{*}\right)$ & $0.031396\left(0.0943^{*}\right)$ \\
\hline \multirow{6}{*}{$\begin{array}{l}\text { Diagnostics } \\
\text { Pvalues }\end{array}$} & Ramsey RT Stability & 0.3550 & 0.7076 \\
\hline & HTBPG & 0.2055 & 0.4581 \\
\hline & $L M T$ & 0.3534 & 0.4678 \\
\hline & Normality & $0.0002^{*}$ & 0.78638 \\
\hline & CUMSUM & WB & WB \\
\hline & CUMSUM SQUARES & WB & WB \\
\hline ARDL selected Model & Akaike Info Criterion & $(4,0,0,0,0)$ & $(3,3,1,1,3)$ \\
\hline
\end{tabular}

Source: Author's computation from Eviews 9; WB= Well Behaved

Table 8. FDI Inflows and Trade Robutness (Openness)

\begin{tabular}{|c|c|c|c|}
\hline & & Ghana & Nigeria \\
\hline Bound Test & Fstat & 14.78 & 6.1095 \\
\hline \multirow{2}{*}{$\% 5$} & $I 0$ & 2.86 & 2.86 \\
\hline & $I 1$ & 4.01 & 4.01 \\
\hline Cointeg EQ & Coeffient & -1.5606 & -2.6530 \\
\hline \multirow{5}{*}{ LongRunForm } & Pvalue & $(0.0000)$ & $(0.0000)$ \\
\hline & LnFDIpos & $-0.0056\left(0.8424^{\star}\right)$ & $0.1758(0.0001)$ \\
\hline & LnFDIneg & $-0.01949\left(0.6683^{*}\right)$ & $0.2259(0.0054)$ \\
\hline & $\operatorname{LnODA}$ & $-0.08484\left(0.3322^{*}\right)$ & $-0.00813\left(0.1188^{*}\right)$ \\
\hline & LnPOP & $-0.2218\left(0.6043^{*}\right)$ & $-0.22786\left(0.5901^{*}\right)$ \\
\hline \multirow{6}{*}{$\begin{array}{l}\text { Diagnostics } \\
\text { Pvalues }\end{array}$} & Ramsey RT Stability & 0.5054 & 0.8532 \\
\hline & HTBPG & 0.7739 & 0.9409 \\
\hline & $L M T$ & 0.8114 & 0.9379 \\
\hline & Normality & 0.08863 & 0.6369 \\
\hline & CUMSUM & WB & WB \\
\hline & CUMSUM SQUARES & WB & WB \\
\hline ARDL selected Model & Akaike Info Criterion & $(2,0,1,0,2)$ & $(3,0,4,1,4)$ \\
\hline
\end{tabular}

Source: Author's computation from Eviews 9; WB= Well Behaved

Tables 8 and 9 captured the asymmetric impact of FDI inflow and ODA inflow on trade openness in Ghana and Nigeria. There are robust studies on the impact of trade openness on economic growth. In this study, our task is to consider the impact of FDI inflow and ODA inflow to improve the ratio of external trade to GDP. Asymmetric cointegrating framework impact measures the impact of the increase and the decrease in FDI inflow and ODA inflow and the corresponding impact on the ratio of the sum of trade export and import to GDP. In Tables $\mathbf{8}$ and $\mathbf{9}$ there is a long-run relationship between FDI inflow and ODA inflow and trade openness in Ghana and Nigeria. Changes in FDI inflows generate a negative impact on trade openness in Ghana and a mixed impact on Nigeria. As FDI inflow increased into Ghana and Nigeria, there is a $0.5 \%$ fall in trade openness in Ghana, a $17.5 \%$ rise in trade openness in Nigeria. Thus, FDI inflow accelerates external trade/GDP in Nigeria and does not facilitate external trade/GDP in Ghana. The Decrease in FDI inflow negatively affects external trade/GDP by $1.9 \%$ in Ghana and positively impact on external trade/GDP in Nigeria by $22.5 \%$.

A positive rise in ODA inflow into Ghana and Nigeria shows a negative impact on trade openness by $3.8 \%$ in Ghana and $11.3 \%$ in Nigeria. A decline in ODA inflow positively impact trade openness in Ghana by $1.7 \%$ and negatively impact on trade openness in Nigeria by $46.6 \%$.

\section{DISCUSSION OF FINDINGS}

The essence for introducing COVID-19 is based on the volatility it has generated in the financial global space. This impact of COVID-19 has injected dynamical changes in the movement of capital flow. Hence it is from this underlying circumstance we adopted NARDL to empirically identify the impact countries such as Nigeria and Ghana are exposed to as the lockdown fiscal policy continues.

Dynamical movement of FDI inflow and ODA inflow into Ghana and Nigeria has a long-run relationship with growth and selected trade indicators hypothesized in this study, except for FDI inflow on RGDP in Ghana. The long-run relationship between capital inflows and growth and selected trade indicators deepens policy options by policymakers to achieve SDGs in Ghana and Nigeria. In another context, the long-run relationship between capital inflows and macroeconomic indicators could imply that the 
Table 9. ODA Inflows and Trade Robustness (Openness)

\begin{tabular}{|c|c|c|c|}
\hline & & GHANA & NIGERIA \\
\hline Bound Test & Fstat & 20.105 & 5.832 \\
\hline \multirow{2}{*}{$\% 5$} & I0 & 2.86 & 2.86 \\
\hline & $I 1$ & 4.01 & 4.01 \\
\hline Cointeg EQ & Coeffient & -2.6536 & -2.3256 \\
\hline \multirow{5}{*}{ LongRunForm } & Pvalue & $(0.0001)$ & $(0.0000)$ \\
\hline & LnFDI & $0.07162(0.0316)$ & $0.1265(0.0163)$ \\
\hline & LnODApos & $-0.0380\left(0.6539^{*}\right)$ & $-0.11328\left(0.0738^{*}\right)$ \\
\hline & LnODAneg & $0.017008\left(0.8160^{*}\right)$ & $-0.46626(0.0002)$ \\
\hline & $\operatorname{LnPOP}$ & $-0.61310\left(0.2305^{*}\right)$ & $-2.2229(0.0000)$ \\
\hline \multirow{6}{*}{$\begin{array}{l}\text { Diagnostics } \\
\text { Pvalues }\end{array}$} & Ramsey RT Stability & $0.0401^{\star}$ & 0.4626 \\
\hline & HTBPG & 0.1166 & 0.9331 \\
\hline & LMT & 0.3072 & 0.0923 \\
\hline & Normality & 0.9114 & $0.0026^{\star}$ \\
\hline & CUMSUM & WB & WB \\
\hline & CUMSUM SQUARES & WB & WB \\
\hline ARDL selected Model & Akaike Info Criterion & $(4,4,3,4,2)$ & $(4,4,3,0,4)$ \\
\hline
\end{tabular}

Source: Author's computation from Eviews 9; WB= Well Behaved

dynamical impact of FDI inflow and ODA inflow are important policy indicators that could, in the long-run, affect the macroeconomic stability and sustainability of growth required to combat poverty and improve inclusive growth rate in Ghana and Nigeria. There are traces of shocks generated from global capital inflows in Ghana and Nigeria. The traces of instability can be viewed from the results got from Ramsey Stability in: Tables 2 and 3, FDI/ODA inflow causes shock in Real GDP; Table 6 FDI inflows on multilateral trade, Table 9 ODA inflows on trade robustness (openness).

The result implies therefore, global capital inflows policy is a veritable instrument for enhancing growth and trade. Thus policy to improve the establishment of SEZs, GVC, and MNEs production are vital to expand the frontier of Ghana and Nigeria to achieving SDGs. However, using SEZs to attract capital inflows has not in itself guarantee robust growth. Thus, the number of SEZs in Ghana and Nigeria could not account for significant capital inflow to drive robust growth and trade. This is because; capital inflow could have been insignificant to expand growth and trade. In spite of the long-run relationship, the long-run impact of capital inflows connotes that the fluctuations in capital inflows e.g. FDI inflows and ODA inflows that are attracted into Ghana and Nigeria are relatively less significant to drive robust macroeconomic frontier and could be interpreted as being a window to shocks. Notwithstanding the level of infinitesimal and a negative impact of global capital inflow on growth and trade shown in Tables 29, also, the elasticity of changes in FDI inflow and ODA inflow brings about an inelastic impact on macroeconomic indicators. This impact could affect the imperativeness of pillar III (financial integration policy) of the Banjul Action Plan (BAJ) in Ghana and Nigeria. Thus, the inelastic and mixed impact on capital inflows on the growth and trade in Ghana and Nigeria implies that the economies are susceptible to volatility in global capital inflow. In the long-run, the common policy administration through West Africa Central Bank might have to deal with several shocks to deal with administering policy direction for the West African monetary zone which Ghana and Nigeria belong to.

Although, there is no long-run relationship between FDI inflow and long-run growth forecast in Ghana; the dynamical changes viz-a-viz a proportionate rise in the inflow of FDI into Ghana produced a positive impact on Ghana's long-run growth. The implications of these findings clearly show that Ghana is affected by any perceptible changes in the direction of FDI. More so, a decrease in FDI inflow does not significantly impact growth in Ghana. In the case of Nigeria, there is a negative impact on growth as FDI inflow increases and decreases. Volatility in the inflow of FDI sends undesirable impact factors that improve growth in Nigeria. The impact of the Increase in FDI inflow in the long-run is desirable in Ghana than in Nigeria. However, a decrease in FDI inflow produced a negative impact in Nigeria. It could imply that Ghana has a robust economic space to counteract volatile shocks in the number of capital inflows than Nigeria. The result, consequently, connotes that the degree of responsiveness change in the inflow of FDI, there is a fairly inelastic positive change in Ghana's long-run growth and there are fairly inelastic negative responses in Nigeria's long-run growth. The impact of any perceptible change in ODA inflow on growth in Ghana and Nigeria is well-behaved. An increase in the inflow of ODA generated a positive and desirable impact on growth. Ghana's growth behaves robustly than Nigeria's growth. Also, negative ODA inflow leads to negative growth in Ghana and Nigeria. From this result, a positive rise in ODA inflow desirable for both countries, and on the other hand decrease in ODA inflow generates a negative (insignificant) impact on growth in Ghana and negative (significant) impact on growth in Nigeria.

We noticed that changes in the inflow of FDI and ODA produced an undesirable impact on trade (\% of GDP). It is obvious that FDI/ODA inflows have a negative impact on trade. This result contradicts the global response in terms of the aid-flow to trade in developing economies (see Amaefule et al., 2019). The impact is significant in Ghana and insignificant in Nigeria. The result could imply that trade size does not response to rising FDI inflow and ODA inflow. To further deepen the result on trade, this paper also examined how FDI inflow and ODA inflow satisfactory improve inter-regional trade in terms of multilateral trade (proxy by merchandise of export within region see World Bank Data) within the region of Ghana and Nigeria and trade openness. The coefficients of multilateral trade and trade openness response in Ghana are negative and insignificant by a one percent change in FDI/ODA inflow except for a decreasing ODA inflow which appeared positive in Ghana. But in Nigeria, dynamical movements in FDI inflow do not affect its multilateral or inter-regional trade and trade openness, as FDI inflow impact is insignificantly positive. ODA inflow is insignificantly negative. Thus, FDI/ODA inflow on multilateral trade and trade openness (statistically mixed). However, the impact of FDI inflow is marginally positive in Nigeria. This implies that a rise in FDI inflow has impacted more on Nigeria than 
in Ghana to build responsive capacity to export. In terms of ODA inflow, ODA inflow is yet to expand the frontier of multilateral export trade capacity and trade openness in Ghana and Nigeria. The implication is that Nigeria's response to export within the region and trade openness is positively elastic. The result might connote that ODA inflow has not perceptibly improved interregional trade in Ghana and Nigeria.

The Ramsey RT, HTBPG, LMT, Normality test and CUMSUM and CUMSUM squares in Tables 2-9 are stable except for FDI inflow and ODA inflow on RGDP and FDI impact on multilateral trade in Ghana. The implication of the result, therefore, implies that a stabilization policy has to be implemented to realize the full potentials of FDI inflow and ODA inflow in Ghana and Nigeria.

\section{CONCLUSION AND RECOMMENDATIONS}

Accelerated investment drives growth and trade. The impact of volatility (e.g. COVID-19 pandemic and slump in global oil price) has grossly affected the global investment climate. The global investments from MNEs, IOC, and M \& A are currently plummeting due to COVID-19. Global reinvested earnings derived from MNEs profits (a major component of FDI and ODA) have declined due to COVID-19. It is based on these dynamics the study desires and thus this trajectory slows country's capacity to achieve the sustainable development goals. Sustainable development goals 1, 2, 8, and 12 depends on robust growth and trade, through the multiplier effect growth and trade have on key economic agents e.g. private sector, public sector, global investors and household, that drive inclusive development. Thus, expanding the frontiers of economic growth and trade in Ghana and Nigeria would facilitate the ability of countries to gain market share from global trade that would improve the overall living standard in Ghana and Nigeria. But, to achieve sustainable development goals in Ghana and Nigeria, policymakers are often confronted with the problems of fluctuation of capital flows e.g. Foreign Development Investment (FDI), Official Development Assistance (ODA), etc. The management of fluctuation of capital flow is an important decision of policymaker. Therefore, policymakers are consistently overwhelmed with the effects of fluctuation of capital inflows on the macroeconomic outlook. This is because; macroeconomic outlook of any economy would determine to a greater extent the state of the capacity of countries to attain sustainable development goals. There are sparing researches on the dynamical impact of capital inflows on the macroeconomic outlook in Ghana and Nigeria. Thus, a point of departure from previous studies, this study seeks to investigate the dynamical nature of increasing (positive) and decreasing (negative) capital inflows on the behaviour of macroeconomic outlook in Ghana and Nigeria. Two important capital inflows variables were employed they include FDI inflow and ODA inflow. These capital inflows are known by nature dynamically. Previous studies on FDI and ODA have not adequately addressed the implications of the rise (upward) and decline (downward) FDI inflow and ODA inflow and their effectiveness on the macroeconomic performance of Ghana and Nigeria. This study, therefore, compares the relative effectiveness of FDI inflow and ODA inflow on selected macroeconomic variables in Ghana and Nigeria. This paper would, consequently, deepen the debate on the capital-growth hypothesis.

The impact of FDI inflow and ODA inflow on the selected macroeconomic variables is mixed. The asymmetric modelling has revealed the desirability and undesirability of FDI inflow and ODA inflow into Ghana and Nigeria. This result is far imperative for a policy response that previous studies. More importantly, this study is robustly and empirical decomposed to unveil the impact of fluctuation of FDI inflow and ODA inflow. The magnitudes and signs of the coefficient of FDI inflow and ODA inflow have a different impact in Ghana and Nigeria. This result is consistent with extant studies on the globalization of capital movement into developing and emerging economies. Several reasons could be adduced to be responsible for the impact of positive rise FDI inflow and positive rise in ODA inflow. The negative impact on FDI inflow and ODA inflow could imply Stiglitz worries over the globalization of capital movement on developing economies. With a caveat, we argue that Stiglitz's argument might suffice whenever the issue of leadership and institutional factors are captured in examining the relative impact of FDI inflow and ODA inflow into emerging and developing economies in Ghana and Nigeria. From the study we conclude that, the pace of SDGs in Ghana and Nigeria are susceptible to dynamical impact of changes in global capital inflow.

\section{REFERENCES}

Amaefule, C., Onuchuku, O., Kalu, I. E. and Shoaga, A. (2019). Foreign aid for trade, African Continental free trade, and trade volume: Does foreign aid inflow matter in West African Monetary Zone? American Journal of Economics, 9(6), 282-288.

Anyanwu, J. C. (2011). Determinants of foreign direct investment inflows to Africa, 1980-2007. African Development Bank Group, Working paper No136.

Anyanwu, J. C. and Yameogo, N. D. (2014). FDI to Africa: Regional Comparism. Conference paper: International Economic Association World Congress, At King Hussein Bin Talal Convention Center (KHBTCC), Dead Sea, Jordan.

Borensztein, E., De Gregorio, J. and Lee, J-W (1997). How does foreign direct investment affect economic growth? Journal of International Economics,45, 115-135. https://doi.org/10.1016/S0022-1996(97)00033-0

Carkovic, M. and Levine, R. (2002). Does foreign direct investment accelerate economic growth. https://doi.org/10.2139/ssrn.314924

Chenery, H. B. and Strout, A. M. (1966). Foreign assistances and economic development. American Economic Review, 56, 679-733.

De Mello, L. R. (1999). Foreign direct investment-led growth: evidence from time series and panel data. Oxford Economic papers, 51, 133-151. https://doi.org/10.1093/oep/51.1.133 
Ehigiamusoe, K. U. and Lean, H. H. (2019). Foreign capital inflows and Economic growth in Nigeria: Any nexus? Journal of African Business, 20(4), 455-471. https://doi.org/10.1080/15228916.2019.1581010

Igan, D., Kutan, A. M. and Mirzaei, A. (2016). Real effects of capital inflows in emerging market. International Monetary Fund, WP/16/235. https://doi.org/10.5089/9781475558555.001

Ikpesu, F. (2019). Growth effects of capital inflows and investment in Nigeria. International Journal of Management, Economics and Social Science, 8(1), 5-19. https://doi.org/10.32327/IJMESS/8.1.2019.2

Ledyaeva and linden (2006). Foreign Direct Investment and Economic Growth: Empirical Evidence from Russian Regions BOFIT Discussion Paper No. 17/2006. https://doi.org/10.2139/ssrn.1002361

McKinnon, R. I. (1973). Money and Capital in Economic Development, Brookings Institution, Washington D.C.

Mowlaei, M. (2018). The impact of foreign capital inflows on economic growth on selected African countries. African Journal of Economic and Management Studies, 9(4),523-536. https://doi.org/10.1108/AJEMS-01-2018-0021

Romer, M. P. (1994). The origins of endogenous growth. Journal of Economic Perspective, 8(1), 3-22. https://doi.org/10.1257/jep.8.1.3

Sedai, A. K. (2019). Why so serious about Foreign Capital? International Journal of Financial Studies, 7(47), 1-15 https://doi.org/10.3390/ijfs7030047

Shaw, E. S. (1973). Financial Deepening in Economic Development. New York: Oxford University Press.

Tang, S., Selvanathan, E. A. and Selvanathan, S. (2008). Foreign Direct Investment, domestic investment, and economic growth in China: A time series analysis No 19, WIDER Working Paper Series from World Institute for Development Economic Research (UNU-WIDER). https://doi.org/10.1111/j.1467-9701.2008.01129.x

UNCTAD (2018). Special Economic Zones Chapter IV, 1-80.

UNCTAD (2018). World Investment Report, 2019, Africa.

UNCTAD (2018). World Investment Report, 2019, Ghana.

UNCTAD (2018). World Investment Report, 2019, Nigeria.

UNCTAD (2020). Investment Trends Monitor (March Special Issue).

UNDP (2015). Sustainable Development Goals.

World Bank (2019). World Development Indicators. 